\title{
The waveform inversion of mainshock and aftershock data of the 2006 M6.3 Yogyakarta earthquake
}

\author{
Hijrah Saputra ${ }^{1}$, Wahyudi Wahyudi ${ }^{1}$, Iman Suardi $^{2}$, and Wiwit Suryanto ${ }^{1^{*}}$ \\ ${ }^{1}$ Department of Physics, Faculty of Mathematics and Natural Sciences, Universitas \\ Gadjah Mada, Yogyakarta, 55281 Indonesia \\ ${ }^{2}$ The Agency for Meteorology, Climatology, and Geophysics of Indonesia, Jakarta \\ 10720 Indonesia \\ *Correspondence: ws@ugm.ac.id
}

\section{Abstract}

This research was examines the focal mechanism associated with the mainshock and three aftershocks of the magnitude 6.3 Yogyakarta earthquake on May 27, 2006. This study, therefore, aims to provide a clearer answer on the source mechanism of the earthquake, which has been debated. Data were obtained from the mainshock and aftershock sources, on June 8,9 , and 16, 2006. The mainshock and three aftershocks were used to conduct waveform inversion by calculating the Green's functions through the extended reflectivity method of the near-field and the far-field signal component. The mainshock's focal mechanism has a strike, dip, and range angle of $243.40^{\circ}, 77.50^{\circ}$, and $-28.30^{\circ}$, respectively.

Furthermore, the mainshock is not a pure strike-slip as previously hypothesized. The focal mechanism for the aftershock earthquake source on Mw 4.4, obtained on June 8, had a strike, dip, rake, and variance of $192.20^{\circ}, 29.70^{\circ},-48.30^{\circ}$ and 0.22 , respectively. This aftershock had a different segment from the mainshock event and those obtained on the 9 and 16 of June with the same type of faulting as the mainshock with variance values of 0.195 and 0.243 . These results showed that the mainshock of May 27, 2006, activated the aftershock on June 8, with a different type of fault. 
28 Keywords: mainshock; aftershock; inversion; moment tensor; extended reflectivity; near-

29 field

\section{Introduction}

In the early hours of May 27, 2006, at approximately 05.54 local times, an earthquake struck the city of Yogyakarta. Based on the Agency for Meteorology, Climatology, and Geophysics of Indonesia (BMKG) stated that the earthquake had a magnitude of $\mathrm{Mw}=6.3$, centered at $8.030 \mathrm{E}$ and $110.320 \mathrm{~S}$, with a depth of $11.87 \mathrm{~km}$ at the southeast of the city of Yogyakarta as shown in figure 1. It was declared the deadliest shallow earthquake in Indonesia (BMKG, 2006). This earthquake destroyed most of the infrastructure in the region of Yogyakarta and Klaten, Central Java Province. The reports by the National Development Planning Agency (BAPPENAS) in cooperation with the Yogyakarta Special Region Government (DIY), Central Java Provincial Government, and international partners in 2006 stated that the Yogyakarta earthquake killed more than 5000 people, with 38,000 injured, 423,000 evacuated, and 156,000 buildings destroyed (Bappenas, 44 2006).

45 Earthquake focal mechanism is used to obtain valuable information on the source parameters such as magnitude, fault orientation, and stress field. This instrument varies

47 from several agencies such as Indonesia Meteorology Climatology and Geophysics 48 (BMKG, 2006), United States Geological Survey (USGS, 2006), National Earthquake Information Center (NEIC, 2006), Kandilli Observatory and Earthquake Research Institute (KOERI, 2006), European Mediterranean Seismological Center (EMSC, 2006), and

51 Institute de Physique du Globe de Paris (IPGP, 2006).

52 Debates on the source of the Yogyakarta earthquake is still in progress. Most researchers 53 believe that the earthquake did not originate from the geological fault along the Opak's 54 river, because the aftershock was distributed $10-15 \mathrm{~km}$ on the east side (Walter et al., 55 2007, Wulandari et al., 2018). Some researchers also believe that the earthquake has 
56 reactivated some minor faults on the east side of the Opak fault (Budiman et al, 2019, 57 Irham et al, 2014). Saputra et al. (2018), stated that the Opak river consists of 56 faults 58 with a maximum displacement of $2.93 \mathrm{~m}$. Meanwhile, the results obtained by Nakano et 59 al., (2006) also had a different focal mechanism, as shown in figure 1. According to 60 studies, several factors influence this difference, such as the lack of a seismometer 61 network of BMKG's, which existed before 2006. This led to differences in the level of 62 location accuracy, source depth, and fault orientation (Ma and Eaton, 2011, Saunders et 63 al, 2016).

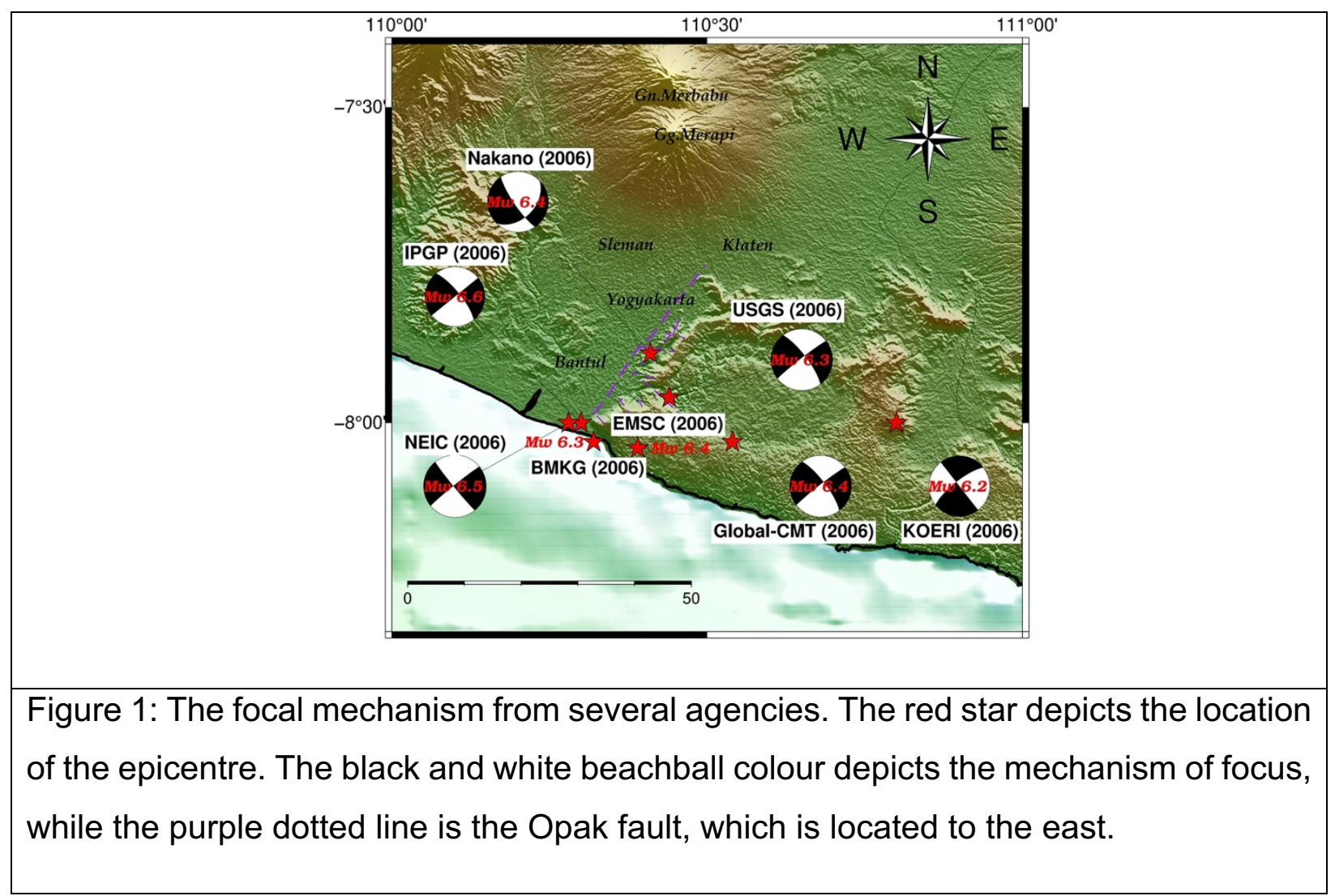

65 The parameters of the earthquake sources from various institutions are shown in Table 66 1. Majority concluded that the epicenter is on the east side of the Opak fault which also 67 indicates consistency by the aftershock distribution (Walter et al., 2008). 
71 Table 1: Parameters of Yogyakarta earthquake from various agencies (Elnashai et al., 72 2006)

\begin{tabular}{|c|c|c|c|c|c|c|c|}
\hline \multirow{2}{*}{ Agencies } & \multirow{2}{*}{$\begin{array}{c}\text { Event } \\
\text { Time } \\
\text { (WIB) }\end{array}$} & \multirow{2}{*}{$\begin{array}{c}\text { Depth } \\
(\mathbf{k m})\end{array}$} & \multicolumn{3}{|c|}{ Magnitude } & \multicolumn{2}{|c|}{ Epicentre } \\
\hline & & & $\mathbf{M}_{\mathbf{b}}$ & $\mathbf{M}_{\mathbf{s}}$ & $\mathbf{M}_{\mathbf{w}}$ & $\begin{array}{l}\text { Latitude } \\
\text { (S) }\end{array}$ & $\begin{array}{l}\text { Longitude } \\
\text { (E) }\end{array}$ \\
\hline BMKG & $5: 54: 01$ & 11.87 & 5,9 & & & -8.03 & 110.32 \\
\hline USGS & $5: 53: 38$ & 12.5 & & & 6.3 & -7.96 & 110.44 \\
\hline Global CMT & $5: 54: 05$ & 21.7 & 6.0 & 6.3 & 6.4 & -8.03 & 110.54 \\
\hline NEIC & $5: 54: 01$ & 28 & & & 6.5 & -8.00 & 110.28 \\
\hline IPGP & $5: 53: 52$ & 15 & & & 6.6 & -8.00 & 11.3 \\
\hline KOERI & $5: 53: 52$ & 20 & & & 6.2 & -8.00 & 110.8 \\
\hline EMSC & $5: 53: 58$ & 10 & & & 6.4 & -8.04 & 110.39 \\
\hline
\end{tabular}

74 Kawazoe and Koketsu, (2010) determined the focal mechanism of the Yogyakarta 75 earthquake using the waveform inversion method. They compared the inversion with the 76 observed data using the CRUST2.0 velocity model (Bassin et al., 2000) as well as the 77 left-lateral strike-slip and reverse dip-slip. Nakano et al. (2006) examined that the focal 78 mechanism dominated by strike-slip. Similar results were obtained by Abidin et al., 2009 79 through the Global Positioning System (GPS) data. The result showed that the horizontal 80 coseismic displacement took place around Bantul and Yogyakarta in the south and 81 southwest direction, with the focal mechanism in the form of left-lateral strike. Tsuji et al. 82 (2009) stated that coseismic displacement and strike-slip along the fault plane also 83 reverses on the east side, which experiences upward displacement. Several studies show 84 that there are different opinions regarding the source mechanism of the Yogyakarta 85 earthquake.

86 Therefore, the paper aims to ascertain the type of faulting based on the main event and 87 three aftershocks with magnitudes $\mathrm{Mw}>=4$. It further characterizes the relationship 88 between the mainshock and aftershock. This research was conducted through the 
89 calculation of moment tensor inversion based on the matching between observed and synthetic waveform.

\section{$91 \quad$ 2. Data and Methods}

92 Data associated with the waveform were obtained from the Incorporated Research 93 agencies for Seismology (IRIS) i.e. XMIS, SBJI, TNG, JCJI, BJI, KMMI, and DNP stations. 94 These data were freely downloaded through the IRIS data services website 95 (http://ds.iris.edu), with the distribution of IRIS and BMKG networks for all stations shown 96 in Figure 2. The waveform data for the aftershock were obtained from the non-permanent 97 seismometer installed by Universitas Gadjah Mada in cooperation with the GFZ, 98 Potsdam, Germany. It consists of ten stations with three component sensors, as shown 99 in figure 3. The experiment found approximately 524 aftershock events that are relocated and plotted to visualize the spatial distribution, as shown in Figure 2.

101 This study, processed the largest magnitude afershock (Mw >=4) from Mw 4.4 June 8, 102 Mw 4.1 June 9, and Mw 4.0 June 16, 2006. Analysis of the three aftershocks focal 103 mechanism is used to determine the consistency of the fault direction caused by the 104 mainshock.

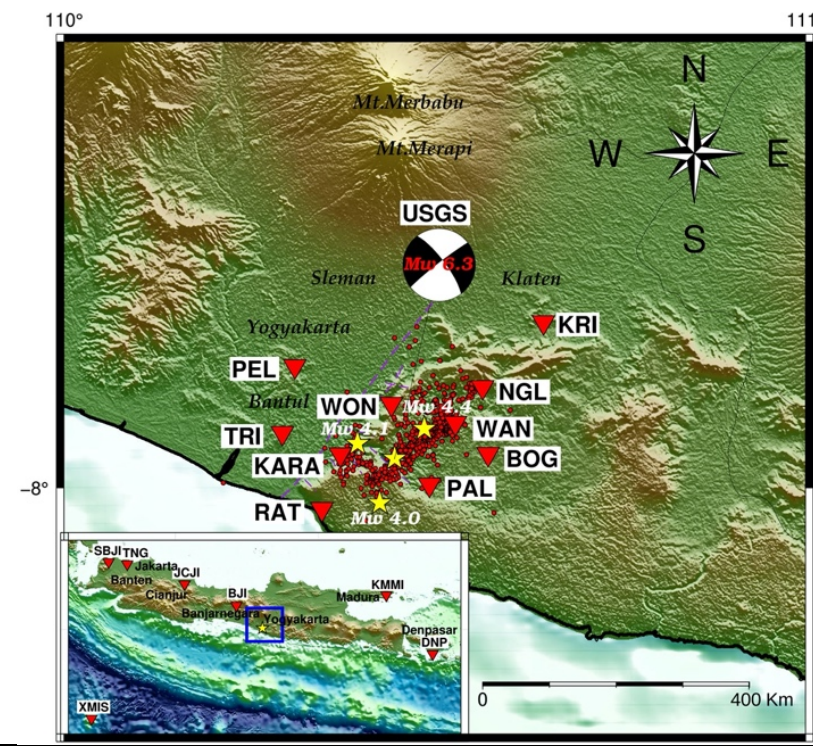

Figure 2: BMKG networks consists of six stations, namely SBJI, TNG, JCJI, BJI, KMMI, and DNP. Meanwhile, the IRIS networks use XMIS stations. The blue box is the 
distribution location of the GFZ non-permanent station (red inverted triangles) as well as the mainshock and aftershock epicentre locations. The yellow star in the blue box depicts the epicentre of the Yogyakarta earthquake mainshock. The black and white colour beachball is the main focal mechanism of the USGS.

106 The waveform is corrected from its instrument response using the Fortran code 107 developed by Yagi (2006). The mainshock waveform is windowed with a data length of 108100 seconds starting 5 before the arrival time of the P-wave. Furthermore, the aftershock 109 waveform data is windowed with a length of 50 seconds before the P-wave arrival time. 110 The same filtering parameters used in previous studies, as shown in Table 2, is used to 111 match the observation and synthetic waveform with the smallest variance value. The 112 variance is the comparison between the observation and the synthetic waveform 113 calculated using equation (1) (Yamanaka and Ishida, 1996; , Ito et al., 2004).

$114 \quad \operatorname{Var}=\sum_{j}\left[\frac{\left(u_{j}^{\mathrm{obs}}\left(t_{i}\right)-u_{j}^{\mathrm{cal}}\left(t_{i}\right)\right)^{2}}{\left(u_{j}^{\mathrm{obs}}\left(t_{i}\right)\right)^{2}}\right]$

115 with $U_{j}^{\text {obs }}$ observations waveform at each $j$ station, $U_{j}^{\text {cal }}$ calculations waveform at each $j$ 116 station each at time $t$.

117 The best inversion models are obtained by calculating the moment tensor inversion, 118 which is iterated at the appropriate resampling time value from 0.1 seconds to 10 119 seconds.

120 Table 2: Limits of the frequency range used in several studies.

\begin{tabular}{lccc}
\hline \multicolumn{1}{c}{ Research } & Frequency (Hz) & $\begin{array}{c}\text { Length of Data } \\
\text { (seconds) }\end{array}$ & $\begin{array}{c}\text { Sampling Time } \\
\text { (seconds) }\end{array}$ \\
\hline Nakano et al. (2006) & $0.01-0.02$ & 250 & 0.5 \\
Suardi (2009) & $0.01-0.03$ & 80 & 0.5 \\
Yagi (2003) & $0.0-0.5$ & 120 & 0.25 \\
$\begin{array}{l}\text { Mikumo and Yagi } \\
(2003)\end{array}$ & $0.05-0.5$ & 60 & 0.25
\end{tabular}


122 In this study, the calculation of the Green's function utilized five velocity models, namely:

123 AK135 (Kennett et al., 1995), CRUST2.0 (Bassin et al., 2000 ), PREM (Dziewonski and 124 Anderson, 1981), Jeffreys-Bullen (Jeffreys and Bullen, 1940), and Koulakov et al., 2007.

125 Calculation of the correct Green's function tends to produce a good estimate of the 126 subsurface velocity model. The predetermined velocity model and grid search models are 127 used in the next stage to determine the depth of the hypocenter. The grid search method 128 applied for hypocenter depth ranges from $1 \mathrm{~km}$ to $25 \mathrm{~km}$. In addition, the depth of the 129 hypocenter was determined both for the mainshock and aftershocks.

130 The main equation for this calculation is shown in equation 2, which describes the vertical 131 component of the observation waveform at each $\mathrm{j}$ station as follows:

$$
u_{j}=\sum_{\mathrm{q}=1}^{5} \iiint_{v} G_{\mathrm{jq}}(t-\mathrm{T}, \mathrm{x}, \mathrm{y}, \mathrm{z}) \mathrm{dV}+\mathrm{e}_{0}
$$

where $G_{\mathrm{jq}}$ is a green function of time $t$, and $\mathrm{T}$ is a unit step from the source positions of $\mathrm{x}, \mathrm{y}$, 135 and $z . M_{q}$ is the moment tensor element, $v$ is the volume of the earthquake source space, $136 q$ is the number of free components for the second pair selected, and $e_{0}$ is the observation 137 error. The focal mechanism represents a point source model. Equation (2) can be 138 simplified into a vector shape to form equation (3).

$$
d_{j}=\mathrm{G}\left(T(t), \mathrm{x}_{c}, \mathrm{y}_{c}, \mathrm{z}_{c}\right)_{j} \mathrm{~m}+\mathrm{e}_{j}
$$

141 where $T(t)$ is the source time function in the source centroid, and $x_{c}, \mathrm{y}_{c}, \mathrm{z}_{c}, d$, and $e_{j}$ are data 142 vector errors with $\mathrm{N}$-dimensions. $M$ represents the five dimensions of the parameter model 143 vector, and $G$ is the $\mathrm{N} \times 5$ coefficient matrix. 
144 The solution to the above matrix equation is determined by the least square method when

145 the observation waveform and the convolution of the Green's function with the time

146 function of the source are known. The calculation of Green functions for near-field data

147 uses the extended reflectivity method developed by Kohketsu (1995) and Yagi (2006).

148 3. Results

\subsection{Mainshock event}

At the initial stages, the filter parameter and time were determined by sampling the trial and error using the grid search method. The best bandpass filter range for mainshock

152 and aftershock is $0.01-0.05 \mathrm{~Hz}$, and $0.1-0.3 \mathrm{~Hz}$, respectively.

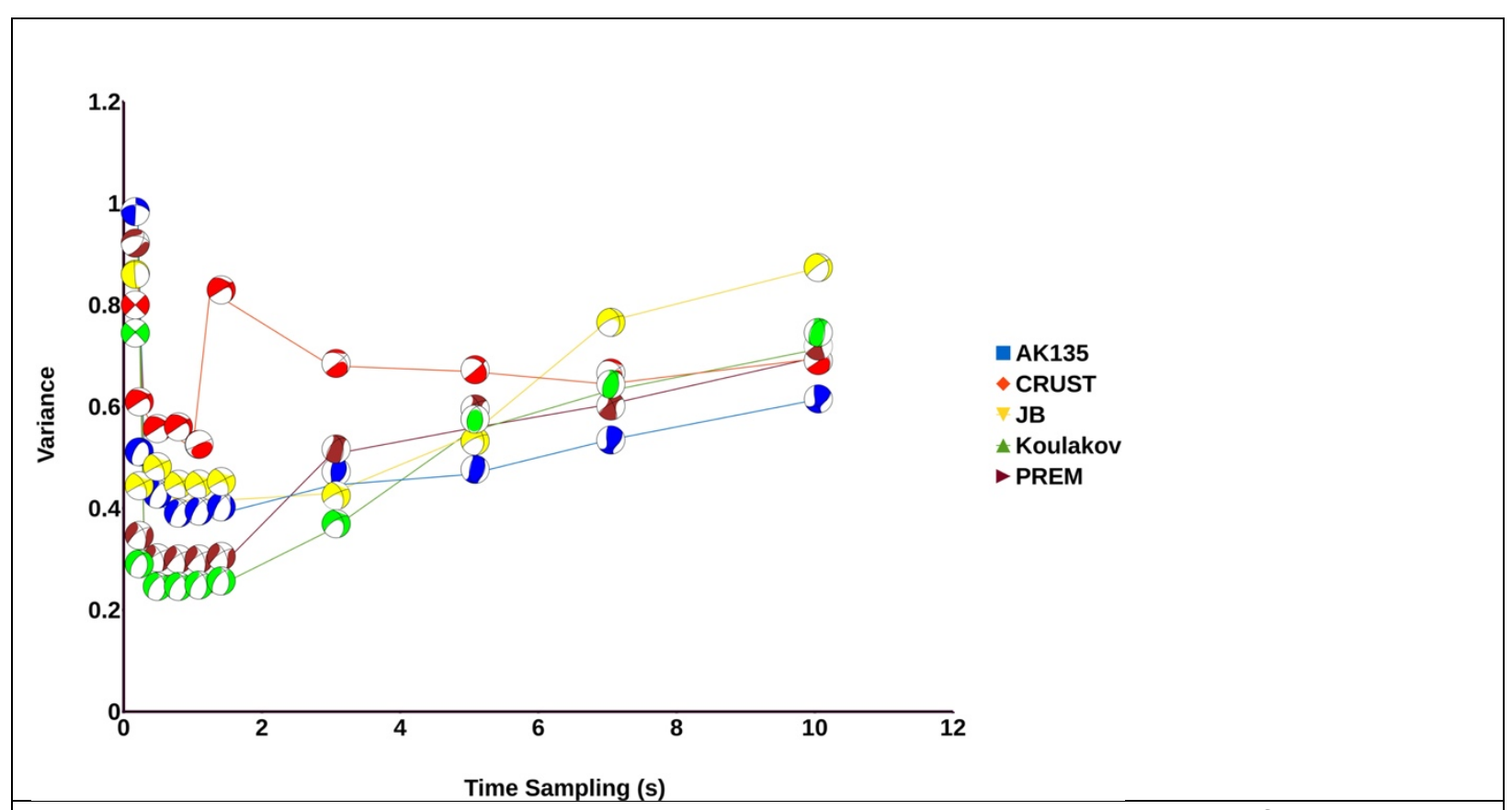

Figure 3: The grid search method between time sampling and the value of the variance of the waveform fitting displacement results for several velocity models. The blue, red, yellow, green, and brown colour beachball indicates the AK135, CRUST2.0, Jeffreys Bullen, Koulakov, and PREM velocity models.

Figure 3 shows the beachball variations for each velocity model and time sampling 154 variation. The time sampling with the smallest variance value of each velocity model is 155 0.5. The slightest grid search process of 0.234 was also obtained using the Koulakov velocity model. The results used to determine the focal mechanism through the grid 
157 search method using a range filter of 0.01 to $0.2 \mathrm{~Hz}$ and some velocity models, as shown 158 in Figure 4. The hypocenter depth with this grid search method through iterations between $1591-25 \mathrm{~km}$ provides a depth step variation.

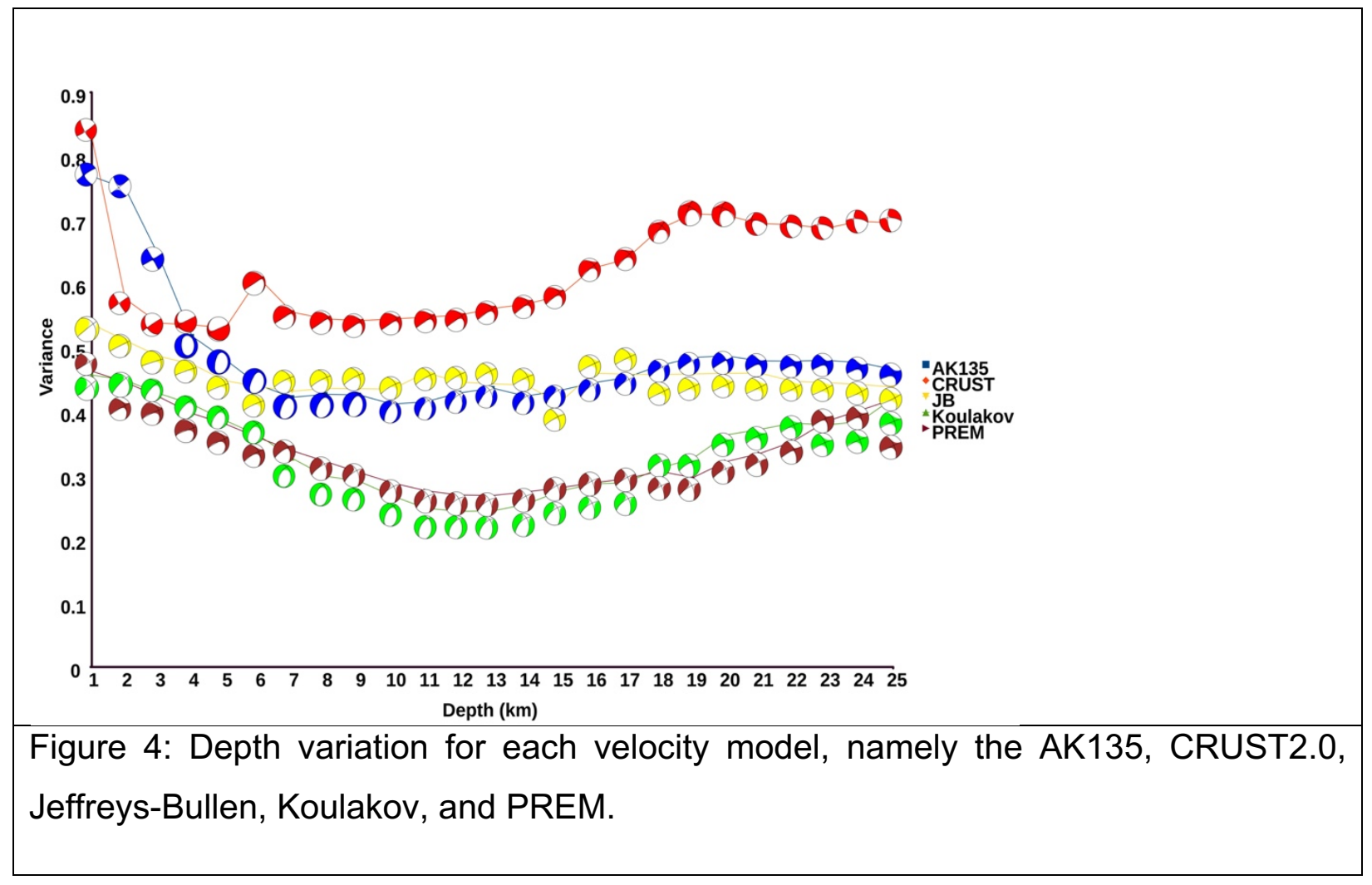

161 The selection of filters with a frequency of $0.01-0.04 \mathrm{~Hz}$ on the mainshock provides stable 162 results using the Koulakov, Jeffrey-Bullen, and PREM velocity models. In contrast, 163 CRUST2.0 and AK135 provide unstable inversion model. At frequencies of 0.01 to 0.02 $164 \mathrm{~Hz}$ with the CRUST2.0 velocity model, and PREM gives a stable inversion model, while $165 \mathrm{AK} 135, \mathrm{JB}$, and Koulakov are not stable. At frequencies of $0.01-0.08$, the velocity models 166 of Koulakov, PREM, and JB are stable while CRUST and AK135 are not stable. At 167 frequencies of $0.01-0.33$, the stable result is given by the velocity models of JB, 168 Koulakov, and PREM, while AK135 and CRUST2.0 are unstable. From these results, the 169 smallest variance values and the most stable result is the Koulakov velocity model.

Figure 4 shows that the grid search method determines the focal mechanism of 171 the mainshock based on the depth variation for each velocity model. A good fit between 
172 the observation and the synthetic waveform was obtained when the hypocenter is located 173 at the depth of $12 \mathrm{~km}$ with a variance of 0.247 .

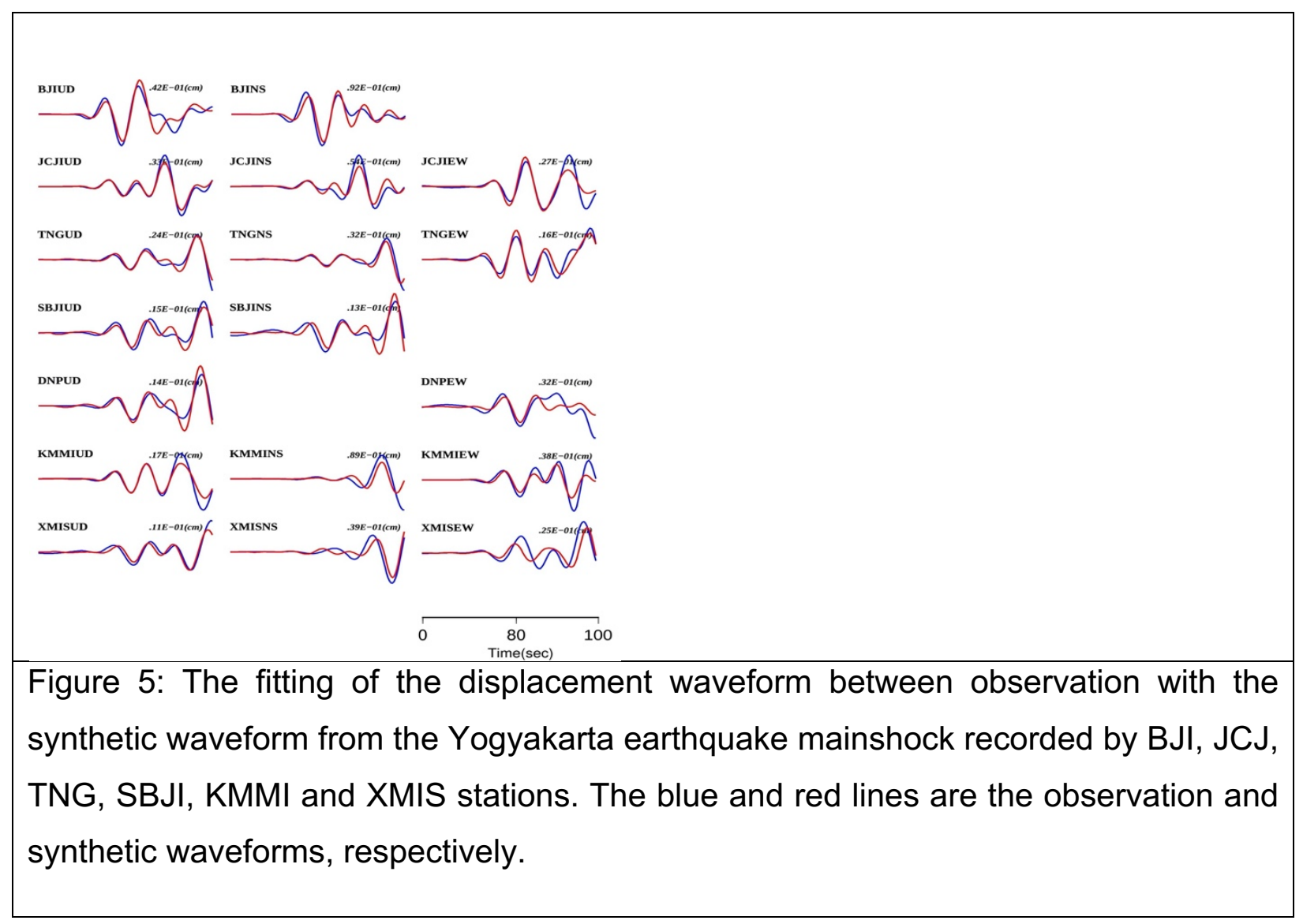

Figure 5 shows the waveform fitting with Koulakov velocity model. It shows the 176 fitting of displacement between the observation and synthetic waveforms of the 177 mainshock from BJI, JCJ, TNG, SBJI, KMMI and XMIS stations, at a good variance value $178 \quad 0.247$. 


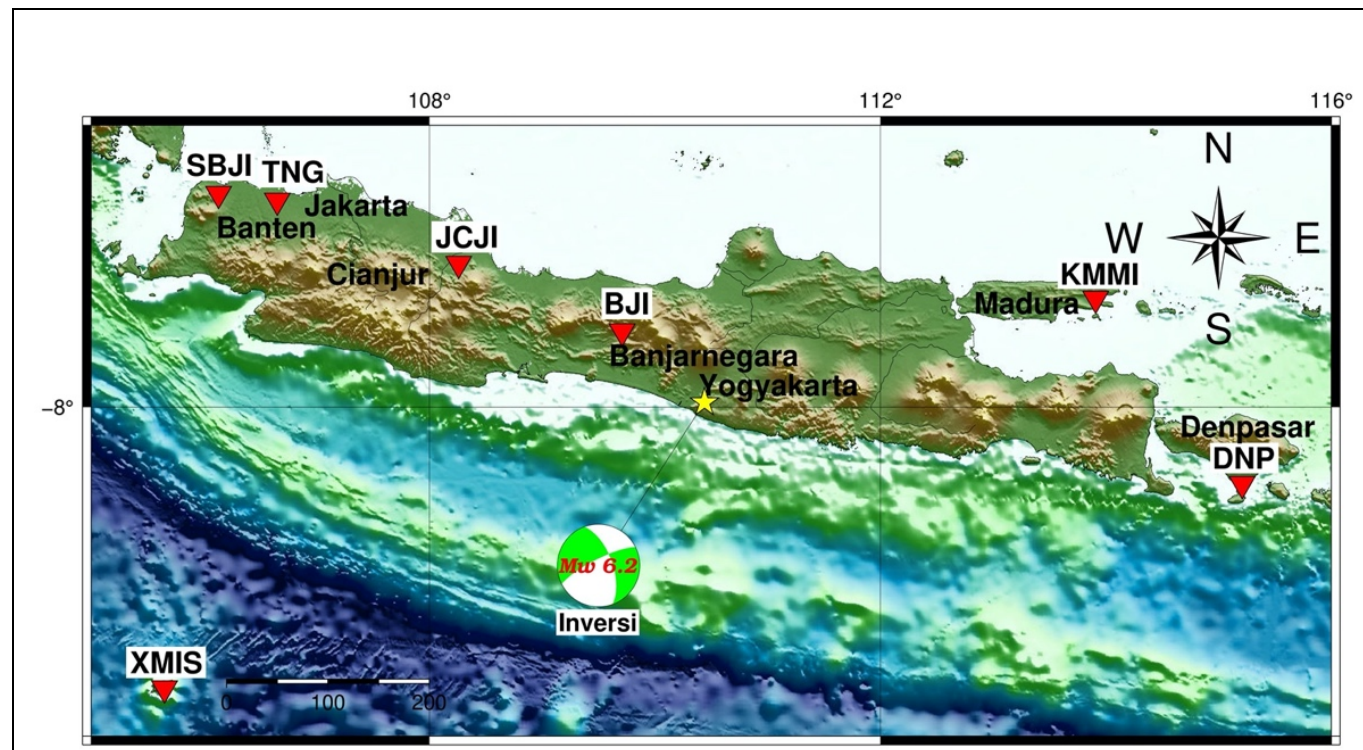

Figure 6: Focal mechanism of the inversion model using Koulakov's velocity model illustrated by a green colour beach ball. The red triangle is the station used for inversion.

180 Figure 6 shows the beach ball focal mechanism based on the inversion model. The fault 181 parameters obtained are strike 340.10 , dip 62.40 , and rake -165.80 for the first nodal 182 solution and strike 243.40 , dip 77.50 and rake -28.30 for the second. The magnitude of 183 the moment produced by this model is $0.2808 \mathrm{E}+19(\mathrm{Nm})$, which corresponds to the 184 moment magnitude $\mathrm{Mw}=6.2$.

\subsection{Aftershocks}

186 The result of the aftershock focal mechanism is shown in Figure 7. Overall, the results 187 based on the waveform fittings have quite small variance values of $0.218,0.195$, and 1880.243 , respectively. 


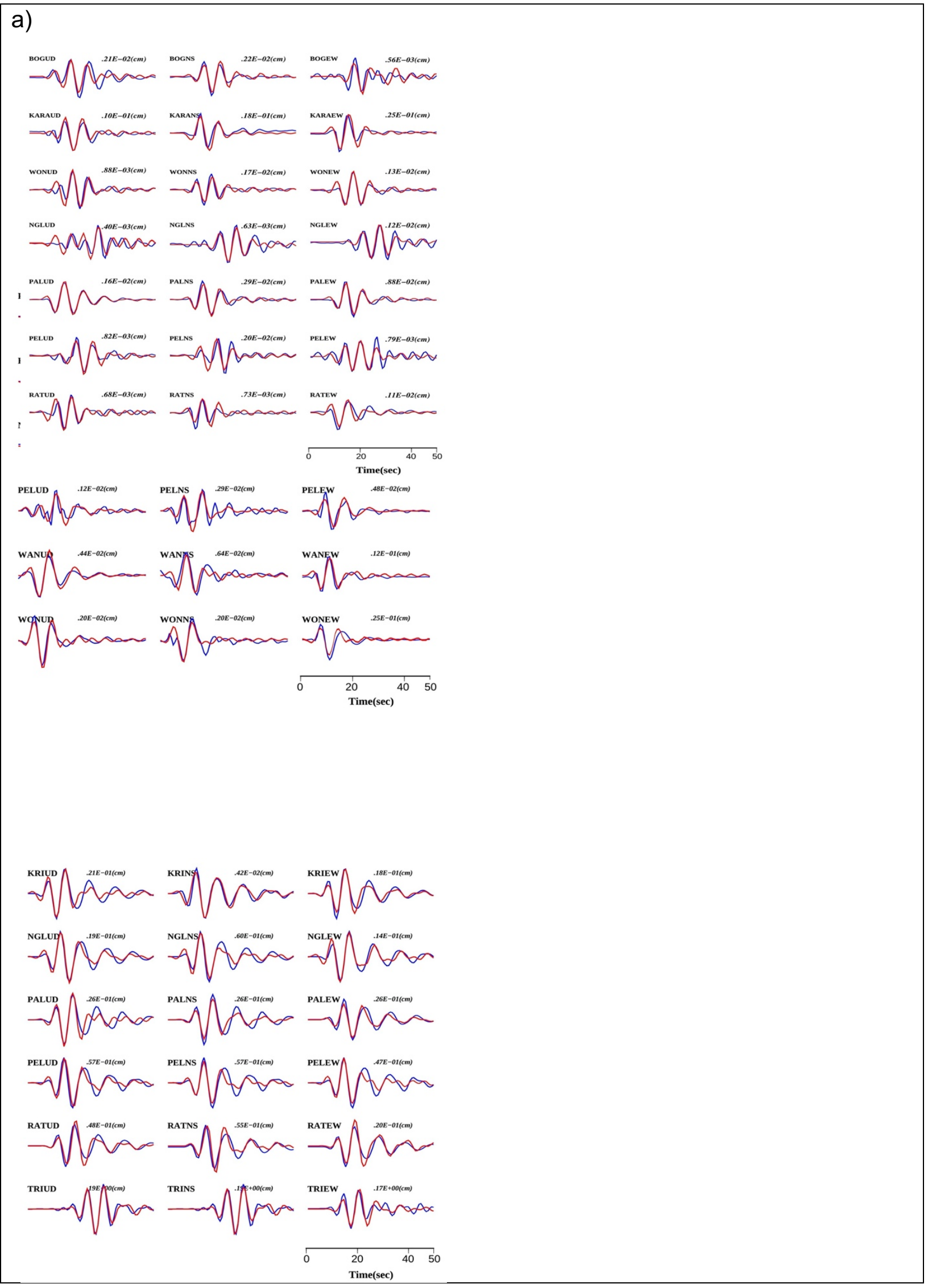


Figure 7: Waveform fitting for the aftershock recorded on 8, 9, and 16 June 2006. The blue and red colours are the observation, and synthetic waveforms, respectively. a) The waveform fitting for aftershock on June 8using PAL, KRI, NGL, PEL, WAN and WON stations. b) The waveform fitting for aftershock on June 9 using KRI, NGL, PAL, PEL, RAT and TRI stations. c) The waveform fitting for aftershock on June 16 using BOG, KARA, WON, NGL, PAL, PEL and RAT stations.

191 Table 3 shows a variation on the fault plane types of aftershock for the 8, 9, and 16 of 192 June 2006. The typical dip-normal was the type of faulting used on June 8, while the 193 strike-slip fault dominated June 9, and 16. The magnitude has a similar result with the 194 catalogue from International Seismological Center (ISC) i.e., $M w=4,4, M w=4,1$ and $195 \mathrm{Mw}=4.0$ for the 8, 9, and 16 June respectively. The variance value obtained from the 196 inversion is shown in Table 3.

198 Table 3: Parameter of aftershock sources obtained in determining the focal mechanism

199

\begin{tabular}{|c|c|c|c|c|c|c|c|c|c|}
\hline \multirow{2}{*}{$\begin{array}{l}\text { Date } \\
\text { (June) }\end{array}$} & \multirow{2}{*}{$\begin{array}{l}\text { Seismic } \\
\text { Moment }\end{array}$} & \multirow{2}{*}{$\begin{array}{c}\text { Depth } \\
\text { (km) }\end{array}$} & \multirow{2}{*}{$\begin{array}{c}\text { Nodal } \\
\text { Plane } 1 \\
\text { (strike, dip, } \\
\text { rake) }\end{array}$} & \multirow{2}{*}{$\begin{array}{c}\text { Nodal } \\
\text { Plane 2 } \\
\text { (strike, dip, } \\
\text { rake) }\end{array}$} & \multicolumn{2}{|c|}{ P Axis } & \multicolumn{2}{|c|}{ T Axis } & \multirow{2}{*}{ Variance } \\
\hline & & & & & Azimuth & Plunge & Azimuth & Plunge & \\
\hline & $0.2636 \mathrm{E}$ & & 192. $2^{0}$ & $326.5^{0}$ & & & & & \\
\hline 8 & $\begin{array}{c}+16, \mathrm{Mw} \\
4.2\end{array}$ & 15 & $\begin{array}{c}29.7^{0},- \\
48.3^{0}\end{array}$ & $\begin{array}{l}68.3^{0},- \\
110.8^{0}\end{array}$ & 25 & 61 & 72 & 21 & 0.2178 \\
\hline 9 & $\begin{array}{c}0.2531 \mathrm{E} \\
+17, \mathrm{Mw} \\
4.1\end{array}$ & 11 & $\begin{array}{l}153.4^{0} \\
69.1^{0} \\
175.6^{\circ}\end{array}$ & $\begin{array}{c}245^{0}, 85.9^{0} \\
20.9^{0}\end{array}$ & 197 & 12 & 291 & 18 & 0.1949 \\
\hline 16 & $\begin{array}{c}0.2342 \mathrm{E} \\
+16, \mathrm{Mw} \\
4.1\end{array}$ & 6 & $\begin{array}{c}87.2^{0} \\
60.7^{0}, 36.9^{0}\end{array}$ & $\begin{array}{l}197.4^{0} \\
58.4^{0},- \\
144.9^{0}\end{array}$ & 211 & 1 & 322 & 1 & 0.2432 \\
\hline
\end{tabular}


201 The results of the aftershock moment tensor inversion is shown in Table 3 and serves as 202 the basis for examining the consistency of the fault plane caused by the mainshock. The 203 beachball solution from this inversion is shown in Figure 8.

\section{Discussion}

The focal mechanism model for the mainshock and aftershock of the Yogyakarta earthquake suggest that the Opak's river fault was not the source (Fukuoka et al., 2006; Diambama et al., 2019; and Nakano, et al., 2006). The gravity study in the Yogyakarta 209 earthquake zone by Irham et al., 2014 also supported this result. Irham et al. (2014) stated that the Siluk fault located at $10 \mathrm{~km}$ to the east of the Opak river fault was the main source

211 of Yogyakarta earthquake.

212

The focal mechanism obtained in this study corresponds to the determination of 213 the focal mechanism by USGS. Initial calculations showed that the fault plane comprises 214 the NE-SW left-lateral strike-slip mechanism. Previous studies are consistent with the 215 location of the aftershock cluster with hypocenter differences spread at a depth of 8-15 $216 \mathrm{~km}$. The focal mechanism obtained is the earthquake rupture on the surface, thereby 217 leading to deformation. The focal mechanism also showed that the geometry of the fault 218 is not straight and appear bent at the southern end with a stretch-like image on the Opak 219 River. The difficulty faced in determining the focal mechanism is due to the direction of 220 the LOS, which is perpendicular to the fault traces, thereby, making it difficult to 221 distinguish the direction of the strike-slip. Tsuji et al. (2009) stated that the coseismic 222 displacement had a reverse component besides the strike-slip along the fault plane, while 223 the east side experienced an upward movement. 


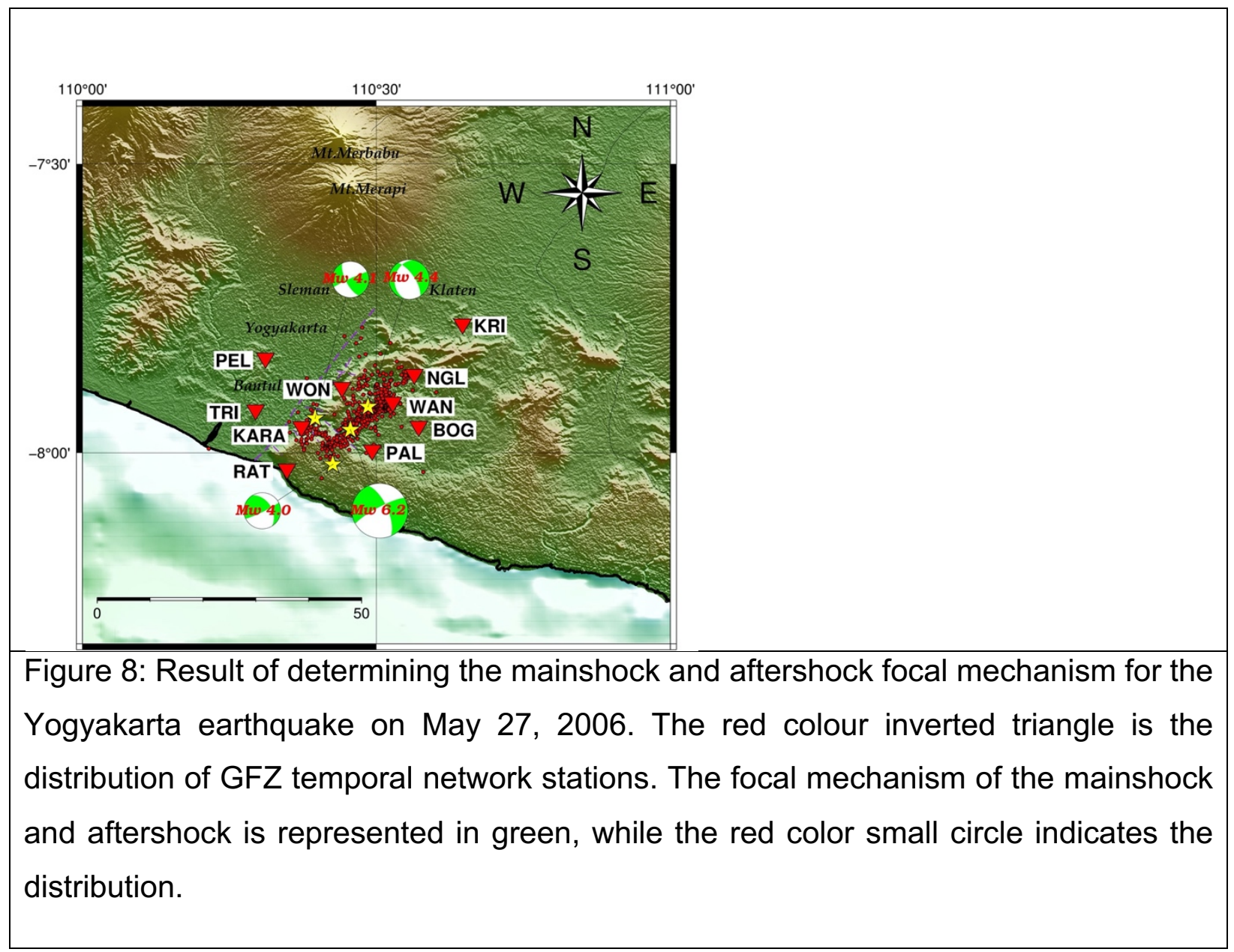

226 Figure 8 shows the results of the moment tensor inversion of mainshock and aftershock.

227 The fault parameters obtained from this model is similar to the USGS report. This showed

228 that the fault source is a strike slip fault with a normal component compared to USGS that 229 defined it as a pure strike-slip fault. Based on the inversion of the aftershock fault 230 parameter on June 8, there is a different focal mechanism than the mainshock, which is 231 dip-normal slip, and it is assumed to be a new earthquake source. The aftershock fault 232 on June 9 and 16 have similarities with the strike-slip fault. 


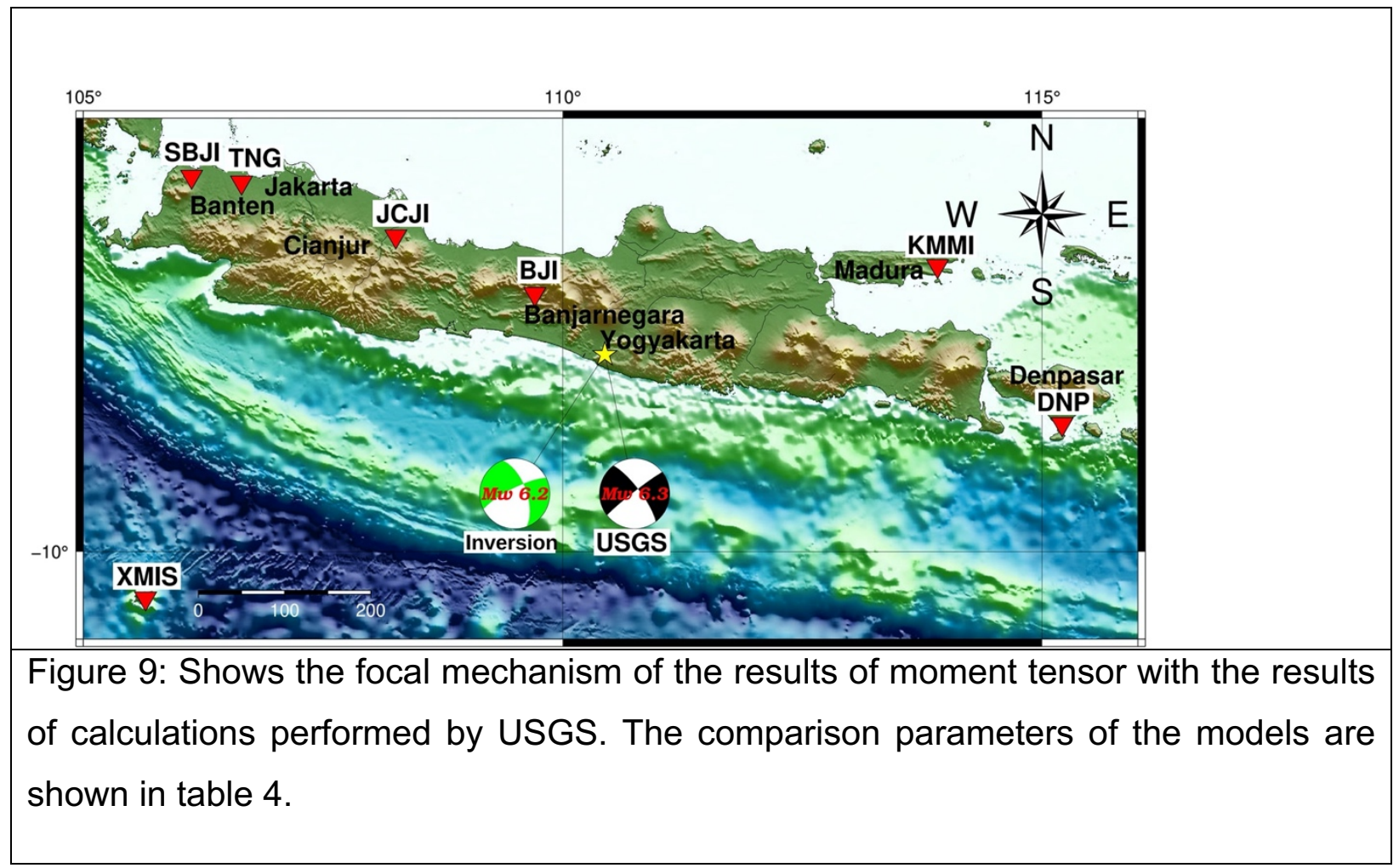

Figure 9 shows the focal mechanism of moment tensor inversion calculations from 236 our study and the solution performed by USGS. The comparison parameters are shown 237 in Table 4.

239 Table 4: Mainshock source parameters obtained in determining the focal mechanism

\begin{tabular}{|c|c|c|c|c|c|c|c|c|}
\hline \multirow{2}{*}{$\begin{array}{l}\text { Source } \\
\text { Parameter } \\
\text { by }\end{array}$} & \multirow{2}{*}{$\begin{array}{l}\text { Seismic } \\
\text { moment }\end{array}$} & \multirow{2}{*}{$\begin{array}{c}\text { Depth } \\
(\mathbf{k m})\end{array}$} & \multirow{2}{*}{$\begin{array}{c}\text { Nodal } \\
\text { Plane } 1 \\
\text { (strike, } \\
\text { dip, rake) }\end{array}$} & \multirow{2}{*}{$\begin{array}{c}\text { Nodal } \\
\text { Plane } 2 \\
\text { (strike, } \\
\text { dip, rake) }\end{array}$} & \multicolumn{2}{|c|}{ P Axis } & \multicolumn{2}{|c|}{ T Axis } \\
\hline & & & & & Azimuth & Plunge & Azimuth & Plunge \\
\hline USGS & $\begin{array}{c}4.22 \mathrm{E}+25 \\
\mathrm{Mw} 6.3\end{array}$ & 21.7 & $\begin{array}{c}323^{0}, 77^{0} \\
-176^{0}\end{array}$ & $\begin{array}{c}232^{0}, 86^{0} \\
-13^{0}\end{array}$ & 187 & 12 & 278 & 7 \\
\hline This study & $\begin{array}{c}0.1893 \mathrm{E}+ \\
19, \mathrm{Mw} \\
6.2\end{array}$ & 20.0 & $\begin{array}{c}323.7^{0} \\
65^{0},- \\
162.7^{0}\end{array}$ & $\begin{array}{c}234.6^{0} \\
74.7^{0},- \\
28.1^{0}\end{array}$ & 185 & 12 & 278 & 6 \\
\hline
\end{tabular}


The results used to determine the mainshock and aftershock focal mechanism for

243 the Yogyakarta earthquake on May 27, 2006, showed the consistency on June 9 and 16,

244 2006. However, there were different patterns of the mainshock and aftershock focal 245 mechanism on June 8, 2006. The aftershock of June 8, 2006, is strongly suspected of 246 being the epicentre that triggered the Yogyakarta earthquake. Further analysis including 247 a full waveform inversion based on earthquake modelling is needed in the area of study 248 to support these findings.

\section{Conclusions}

251 This study suggests that the mainshock of Yogyakarta 2006 earthquake has a focal 252 mechanism of dip-normal strike-slip fault. The aftershock focal mechanism for June 8 253 showed a different fault plane characteristics with the mainshock, while those of 9 and 16 254 had the same fault direction, which is dominantly in strike-slip type. This research shows 255 that the Yogyakarta earthquake has complex fault characteristics caused by the activation 256 of minor faults on the east side of the Opak River. However, these results need further 257 assignment, especially in relation to a significant velocity contrast between the western 258 and eastern parts of the Opak's river fault.

Author Contributions: HS prepared the initial draft article and its analysis, while W corrected, weighed, and analyzed the results. In addition, IS performed data curation, acquisition, and examined the results. WS reviewed, edited, visualized, and analyzed the results. All authors have read and agreed to the published version of the manuscript.

265 Acknowledgment: The authors are grateful to Lembaga Pengelola Dana Pendidikan 266 (LPDP) for funding this doctoral program, as well as to BMKG, IRIS, and GFZ for providing 267 the required waveform data and parameters related to earthquake. The authors also wish 268 to express their profound gratitude to Prof. Yuji Yagi, for developing the script for moment tensor inversion applied in this research. Universitas Gadjah Mada also supported the 
270 study through the Doctoral Program of Physics at the Faculty of Mathematics and Natural 271 Sciences.

272 Conflicts of Interest: The authors declare no conflict of interest.

\section{References}

275 Abidin, H.Z., Andreas, H., Kato, T., Ito, T., Meilano, I., Kimata, F., Natawidjaya, D. H., 276 Harjono, H. 2009, Crustal deformation studies in Java (Indonesia) using GPS, Journal 277 of Earthquake and Tsunami, Vol. 3, No.2, pp 77-88.

278 Bappenas, 2006, Preliminary Damage and Loss Assessment, Yogyakarta and Central 279 Java Natural Disaster, Report of the Ministry of National Development Planning, 280 Republic of Indonesia (Bappenas) with Provincial Government of Yogyakarta Special

BMKG., 2006, Katalog Gempa bumi Signifikan dan Merusak 1821 - 2017, Pusat Gempa bumi dan Tsunami Badan Meteorologi Klimatologi dan Geofisika, Jakarta.

Diambama, A.D., Anggraini, A., Nukman, M., Lühr, B.G., and Suryanto, W., 2019. Velocity structure of the earthquake zone of the M6.3 Yogyakarta earthquake 2006 from a seismic tomography study, Geophysical Journal International, Volume 216, Issue 1, Pages 439-452, https://doi.org/10.1093/gii/ggy430

Dziewonski A. M., and Anderson, D.L., 1981 Preliminary reference Earth model. Physics of the Earth and Planetary Interiors, 25(4):297, ISSN 00319201. DOI: 10.1016/00319201(81)90046-7.

Elnashai, A. S., Jig Kim, S., Jin Yun, G., Sidarta, D. 2006, The Yogyakarta Earthquake of May 27, 2006, MAE Center Report No. 07-02, Mid-America Earthquake Center, Newmark Civil Engineering Lab, University Illinois at Urbana-Champaign. 
EMSC, 2006, Moment Tensors, European Mediterranean Seismological Centre (EMSC), https://www.emsc-csem.org/Earthquake/tensors.php?view=649, accessed on 22 November 2018.

Fukuoka, K, Ehara, S, Fujimitsu, Y, Harmoko, U, Harmoko, U, Setyawan, A, Setiadji, L. D, Harijoko, A, Pramumijoyo, Setiadi, Y, Wahyudi. 2006, Interpretation of the 27 May 2006, Yogyakarta Earthquake Hypocenter and Subsurface Structure Deduced from the aftershock and Gravity Data, The Yogyakarta Earthquake of May 27 2006, Star publishing Company inc.

Global CMT, 2006, Global CMT Catalog Search, The Global CMT (Centroid Moment Tensors) Project, http://www.globalcmt.org/CMTsearch.html, accessed on 20 August 2019.

IPGP, 2006, Moment Tensors, Institute de Physique du Globe de Paris (IPGP), https://www.emsc-csem.org/Earthquake/tensors.php?view=649, accessed on 22 November 2018.

Irham, N. M., Kirbani, S.B., Sismanto, Waluyo. 2014. The subsurface modeling of Opak fault Yogyakarta Region with inversion method of Gravity Data, International Journal of Basic and Applied Sciences IJBAS-IJENS Vol: 14 No:06.

IRIS, 2019, Wilber 3: Select Event, Incorporated Research Institution for Seismology (IRIS) web page, https://ds.iris.edu/wilber3/find_event., downloaded on 2 January 2019.

ISC, 2006, International Seismological Center (ISC) Bulletin: Event Catalogue Search, http://www.isc.ac.uk/cgi-bin/web-db-v4?request, https://doi.org/10.31905/D808B830, accessed on 25 February 2019.

Ito, Y., Matsubayashi, H., Kimura, H., Matsumoto, T., Asano, Y., and Sekiguchi, S. 2004, Spatial Distribution for momen Tensor Solutions of the Tokachi-Oki earthquake (MJMA=8.0) and the aftershock, Earth Planets Space, 56, 301-306. 
324 Jeffreys, H, and Bullen, K.E., 1940. Seismological Tables, British Association for the 325 Advancement of Science, London.

326 Kawazoe, Y., and Koketsu, K. 2010, Source Fault and Rupture Process of the 2006

Kennett, B., Engdahl, E., and Buland, R., 1995. Constraints on seismic velocities in the Earth from travel-times. Geophysical Journal International. 122. 108 - 124. 10.1111/j.1365-246X.1995.tb03540.x.

KOERI, 2006, Moment tensors, European Mediterranean Seismological Centre (EMSC), https://www.emsc-csem.org/Earthquake/tensors.php?view=649, accessed on 11 November 2018.

Kohketsu, K. 1985, The Extended Reflectivity Method for Synthetic Near-Field Seismograms, J. Phys. Earth, 33, 121-131.

Koulakov, I., Bohm, M., Asch, H., Luhr, B.-G, Manzanares, A., Brotopuspito, K.S., Fauzi, Purbawinata, M.A., Puspito, N.T., Ratdomopurbo, A., Kopp, H., Rabbel, W., Shevkunova, E., 2007, P and S velocity structure of the crust and upper mantle beneath central Java from local tomography inversion. J. Geophys. Res, 112, B08310, 18 pp., DOI:10.1029/2006JB004712.

Kuge, K.. (2003). Source Modeling Using Strong-Motion Waveforms: Toward Automated Determination of Earthquake Fault Planes and momen-Release Distributions. Bulletin of The Seismological Society of America - BULL SEISMOL SOC AMER. 93. 639-654. $10.1785 / 0120020076$.

Ma, S and Eaton, D. 2011. Combining double-difference relocation with regional depthphase modeling to improve hypocentre accuracy. Geophysical Journal International. 185. 871 - 889. 10.1111/j.1365-246X.2011.04972.x. 
Mikumo, T. and Yagi, Y., 2003. Slip-weakening distance in dynamic rupture of in-slab normal-faulting earthquakes, Geophysical Journal International, Volume 155, Pages 443-455, https://doi.org/10.1046/j.1365-246X.2003.02047.x.

Miyatake, T, Yagi, Y, and Yasuda, T. 2004, The Dynamic Rupture Process of the 2001 Geiyo Japan Earthquake, Geophysical Research Letters: https://doi.org/10.1029/2004GL019721.

Nakano, M., Kumaga, H., and Miyazawa, K. 2006, Source Estimation of the May 2006 Java Earthquake, EOS, Trans. Am. Geophys. Un, 87.

NEIC, 2006, Focal Mechanism of the 2006 Yogyakarta Earthquake, National Earthquake Information

Center

(NEIC), http://neic.usgs.gov/neis/eqdepot/2006/eq060526neb6/neicneb6q.html, accessed on 14 November 2018.

Saunders, I., Kijko, A., and Fourie, C.J.S., 2016. Statistical evaluation of seismic event location accuracy by the South African National Seismograph Network over four decades. South African Journal of Geology. 119. 291-304. https://doi.10.2113/gssajg.119.1.291.

Saputra, A., Gomez, C., Delikostidis, I., Zawar-Reza, P., Hadmoko, D.S., Sartohadi, J., and Setiawan, M. A., 2018, Determining Earthquake Susceptible Areas Southeast of Yogyakarta, Indonesia-Outcrop Analysis from Structure from Motion (SfM) and Geographic Information System (GIS), Geosciences, Volume 8 No.4, ISSN: 20763263, https://www.mdpi.com/2076-3263/8/4/132.

Suardi, I, 2009, Analysis of Source Rupture Process of the September 2, 2009, Tasikmalaya Earthquake by Using the Joint Inversion Method of Near Field and Teleseismic Data, Dissertation, Study Program of Earth Sciences, Institut Teknologi Bandung, Bandung.

Tsuji, T., Yamamoto, K., Matsuoka, T., Yamada, Y., Onishi, K., Bahar, A., Meilano, I., Abidin, H. Z. 2009, Earthquake fault of the 26 May 2006, Yogyakarta earthquake observed by SAR interferometry, Earth Planets Space, No. 61, pp 29-33. 
USGS, 2006, Earthquake Hazards Program, Momen Tensor, United States Geological Survey (USGS),

web

page.

https://earthquake.usgs.gov/earthquakes/eventpage/usp000ej1c/momen-tensor, accessed on 21 January 2019.

381 Walter, T.R., Luhr, B., Sobiesiak, M., Grosser, H., Wang, R., Parolai, S., Wetzel, H-U., Zschau, J., Milkereit, C., \& Gunther, E., 2007. Soft Volcanic Sediments Compound 2006 Java Earthquake Disaster, EOS, Trans, Am. Geophys. Un., 88, 486, $2007 a$.

Walter, T.R., Wang, R., Luehr, B.-G., Wasserman, J., Behr, Y., Parolai, S., Anggreni, A., Gunther, E., Sobiesiak, M., Grosser, H., Wetzel, H.-U., Milkereit, C., Brotopuspito, K.S., Harjadi, P., Zshau, J. 2008, The 26 May 2006 magnitude 6.4 Yogyakarta earthquake south of Mt. Merapi Volcano: Did lahar deposits amplify ground shaking and thus lead to the disaster, An Electronic Journal of the earth sciences, AGU and the geochemical society, Vol 9, Number 5, DOI:10.1029/2008GC001810.

Wulandari, A., Anggraini, A., and Suryanto, W., 2018. Hypocenter analysis of aftershocks data of the Mw 6.3, May 27, 2006, Yogyakarta earthquake using oct-tree importance sampling method Appl. Mech. Mater., 881, pp. 89-97.

Yagi, Y. 2004, Source rupture process of the 2003 Tokachi-Oki earthquake determined by joint inversion of teleseismic body waves and strong ground motion data. Earth Planet Sp 56, 311-316 (2004). https://doi.org/10.1186/BF03353057.

Yagi, Y., 2006, Earthquake focal mechanism, IISEE Lecture Note 2006-2007, IISEE, BRI, Tsukuba, Japan.

398 Yamanaka, H., and Ishida, H. 1996, Application of Genetic Algorithms to an Inversion of 399 Surface Wave Dispersion Data, Bull. Seism. Soc. Am., 80, 436-444. 